\title{
The hands of the healer: has faith a place?
}

\author{
Gaius Davies Department of Psychiatry, King's College Hospital, London
}

\section{Editor's note}

Dr Davies discusses faith healing, its clients and the healing process. He suggests that typical healers often have a total faith in themselves, their working methods and their systems of belief, sometimes born out of their own previous suffering. Patients do well if they have faith (which needs to be distinguished from credulity) in their healers and this faith should be nurtured and valued. Suggestibility in a patient is highly correlated with the likelihood of a cure. Dr Davies suggests that while physical and psychodynamic explanations may increasingly shed light on the phenomenon of faith healing, there is also increasing public interest in magical and superstitious explanations and techniques. This paper was first presented to a London Medical Group symposium.

My answer to this question is an unequivocal, positive, yes. The faith of the patient or client is vital, but the faith of the healer in what he is doing is just as important. I am sorry to disagree completely with another participant in the symposium for which this paper was prepared: Dr Alec Forbes, the chairman of the Healing Research Trust, states that faith is not necessary and prefers the term natural healing. In a recent interview Forbes ${ }^{1}$ states that his slogan is 'natural healing can refresh the parts of man that other therapies cannot reach'-a witty adaptation of an advertising slogan which does less than justice to a complex problem.

I wish to focus attention first on the healer and the role of faith in his training and approach. The person who seeks healing will then be discussed with particular emphasis on the difference between ignorance and credulity on the one hand, and faith and trust on the other. The healing process has been the subject of much study and will be examined, together with the setting in which the healing takes place. Since the subject of healing has assumed very large proportions in many church circles, the discussion will end with a personal assessment of how the current emphasis on healing compares with a more traditional Christian view of healing.

\section{The healer}

Is there a type, or an archetype? Are we considering the therapeutic personality (whom we have all surely met, who over a cup of coffee can make us feel better by some mysterious alchemy)? Forbes states that 'everyone can heal or be taught to heal and indeed many people are unconscious healers'. Most of us think of the rather exceptional type of person who sets himself up as specially gifted to heal. A list of them would have to include some of the following: Harry Edwards the spiritualist; such Americans as Aimee Semple Macpherson and Kathryn Kuhlman; Christian Scientists like Mary Baker Eddy; parish priests and others following Archbishop William Temple's lead and that of the Churches Council of Healing; Christians of many denominations who (under the influence of the charismatic movement) believe that the gifts of healing which were found in the early church are available and should be in active use today. This long list might easily be multiplied. To it should be added the large number of native healers, traditional healers and the 20,000 natural healers who Dr Alec Forbes estimates are actively or occasionally practising. The longer the list becomes the more disparate the figures which appear in it. Should one include, for instance, President Jimmy Carter's sister Ruth Carter Stapleton whose books are so popular and describe the 'healing of memories'? Do we include the similar approach of the scientologists? And how many Christians (who would shudder at being in a list that frequently includes colourful and maverick characters) would still quietly regard healing as part of their religion. They might say with the famous French Huguenot surgeon Ambroise Paré 'I dressed the wound and God healed him'.

I consider that there is such a thing as the typical healer. One way of delineating him is to consult such an anthropologist as I $M$ Lewis $^{2}$ who has studied and described the native healer or shaman as he appears in different cultures. Lewis shows how a shaman often has to undergo a critical illness and be healed before he then becomes a healer. It is the theme of T S Eliot in the FourQuartets:

The wounded surgeon plies the steel

That questions the distempered part;

Beneath the bleeding hands we feel

The sharp compassion of the healer's art

Resolving the enigma of the fever chart.

Helen Gardner ${ }^{3}$ is doubtless correct in seeing the wounded surgeon as a type of Christ: but I also think Lewis is right in seeing others as, in some sense, an imitation of the same process. In fact Lewis 
during a television debate on the subject went as far as to say that the psychoanalyst undergoing his training analysis was a modern version of the shaman.

I was offered a contemporary example of the making of one modern healer when a patient gave me an American paperback called England's Exorcist tells about Supernaturai Superpowers. This unlikely title is that of a biography of an Anglican priest, Trevor Dearing." He graphically tells of how he was 'a mental and physical wreck as a youngster' and how his psychiatrist diagnosed 'intense hysteria, anxiety neurosis, chronic depression, suicidal tendencies and symptoms of paranoia'. Dearing says 'medical men had written me off as a hopeless case'. He then describes how at nineteen he became a Christian and was then told by his psychiatrist that he did not need to see him again. Later he is advised to become a preacher; later still to take up a healing ministry and again, after a while to become a well-known exorcist. The change in status and the fame is brushed off: "by a strange intervening of circumstances her exorcism was actually televised' writes Dearing of a much publicised case of an alcoholic prostitute. The hopeless case becomes England's exorcist and healer.

Such a dramatic story might be repeated in more muted tones by many healers who have undergone a 'creative illness' which has changed their lives. It may be but a heightening and an accentuating of the experience of many doctors, nurses and others who have chosen their calling after early illness which has given them an insight into the caring professions and a wish to join one of them in later life. My contention is that what marks out the doctor or therapist of any kind who has special success as a healer is his total faith in himself and the system within which he operates. Inside his own system of belief and work, the healer has a superb capacity for rationalising any difficulty and for dismissing any failure.

I do not believe any shaman is a total sham: the more honest and open the character, the less will he succumb to the pressures of publicity, flattery and adulation. But within every doctor there is a charlatan struggling to get out: and if he succumbs to the temptation to ease up on his professional standards he may well be taking the first step in the change from medicine man to mountebank.

Across the spectrum of all professional and other workers who are engaged in any kind of healing, I find that the most successful have a commitment and a belief in their own calling which may be correctly called faith. It is often a faith which has been arrived at after personal suffering and affliction.

\section{The healing seeker}

What of the person seeking healing? First, one may note that they are often (if not anti-doctor) disillusioned by their unrewarding contact with the medical profession. They cannot be expected to honour a physician with the honour due to hi since they are like the woman in the Gospels who had a flow of blood for twelve years. As Marles account puts it she 'had suffered much under many physicians, and had spent all that she had, and not better but rather grew worse'. ${ }^{5}$

No one can deny the importance to the embittered and frustrated patient of any help that faith can bring. But surely faith (in any true sense) must हैe distinguished from both ignorance and credulity. $\vec{\circ}$

Ignorance of the need for something more thin faith may be fatal. I recall an early experience with a devout lady who became hoarse: it was evident that she had a carcinoma of the larynx. In spite her intelligence she was unwilling to be persuaded that surgery or radiotherapy might help her. Either God must heal her, or nothing would be done. Higer decline and death was a very painful process $\$ 0$ observe. It may be that ignorance is only invincible when any new knowledge which contradicts the believer's prejudice is excluded. Certainly it ch lead to fear of 'the surgeon's knife', avoidance of curative medication, and thus result in unnecessagy suffering.

By credulity I understand belief founded on weak or insufficient evidence. Such credulity is endemic in the world of faith healing, even among trained professionals. To be sceptical is to blaspheme sacred tenets. I find that credulity leads to being gullible: in minor matters it may be of little moment, but in life-threatening illness it is a cruel and wanton dioregard of basic human rights to tolerate a credulous acceptance of trickery.

I believe that the faith of the patient is something to be greatly valued: that is why it should distinguished from ignorance and credulity. Faith in this sense may be analysed: it is partly a matte of what makes up the assumptive world of the patient (to use Jerome Frank's ${ }^{6}$ phrase). H expectations of the healer and the healing process are vital: if these are built up the results will be better from any healing. His trust may be partby in the healer as a person who deserves and attracts a feeling that he can be depended upon; or it mas be built upon his fame, or the fact that he is seen as the agent or channel of a higher power. The permutations and possibilities of faith are endlesß No wise surgeon would neglect the importance of his patient's faith in his skill and in the healing possibilities of modern surgery. And as Goldberg points out, the prescription which the patient given will be greatly helped in its efficacy if the patient believes totally in its value.

\section{Diagnosis}

What of the diagnosis in the patient's case, and itg bearing on faith healing? Frequently healers show cavalier disregard of diagnosis, since faith is the 
thing to stress, across the board and irrespective of diagnosis. If the prognosis is grave, some healers only accept this as a challenge to the patient's faith. There seems little doubt that in very many cases that have been documented, the diagnosis shows the patient to be suffering from functional rather than organic disorders. There is often a prevalence of hysterical and psychosomatic disorders. Even in frankly organic diseases the emotional component is the one which the healer aims to relieve most often.

Suggestibility is a personality trait which psychologists can measure: it seems to me one of the most important aspects of whether a patient is going to benefit from healing or not: the more suggestible the client, the more certain the cure is of working.

\section{The healing process}

The process and hypotheses that purport to explain it, have been much studied. Three aspects of its study call for comment: the physical bases for healing, the psychological aspects (as in studies of the placebo effect), and psychoanalytical formulations of healing. Many spiritual healers believe they merely facilitate the natural process of recovery. Thus Dr Christopher Woodard writes': 'To me the most important thing with any kind of disease is to keep your spirit up, and if you can keep above it, you stand a much better chance of neutralising its effect or even reversing the process of the disease'. This line of argument has been used in terms of possible connections between the laying on of hands and the stimulus this produces to release adrenocorticotrophic hormone, which in turn releases cortisone-type hormones. Thus the cripples who throw away their crutches at emotionally-laden healing meetings are merely producing their own internal medication, on this view.

The discovery of endorphins has led to speculation of how pain may be relieved by a placebo injection or tablet which contains no active ingredient. This has been shown to be the case: whether there are similar internal mechanisms to this yet to be demonstrated remains to be seen. It is likely that the more we understand the biochemical mechanisms of the body, the less mysterious will be the physical results of faith healing. Sceptical scientists may then feel happy while believers of various kinds may simply feel that there is 'yet more light to break forth' on how nature (and the God of nature) operates in what used to be called the vis medicatrix naturae.

Studies of the placebo effect are a good example of how it has been shown that the faith of both patient and doctor are important in achieving results. Thus inert pills may produce not simply good effects, but allegedly harmful side-effects: suggesting that it is all in the mind. Red tablets or capsules have been shown to enhance the good effects of such apparently innocuous and ineffective pills. As a result of placebo studies we have scientific evidence for such comments that sage physicians have often made in the past: 'Use a new drug while it works' and 'It matters less what you prescribe than who prescribes it'. For these reasons any trial of a new treatment has to be doubly blind: both the patient and the doctor should be ignorant of which preparation contains the active ingredient, and which is the inert placebo. Clearly such accepted observations as these have great relevance for measuring whether or not the hands of the healer matter, and whether faith in them matters. Yet, like adequate trials of psychotherapy, there is a strange resistance to mounting such experiments as might shed light on faith healing.

A mother, when her child is hurt physically, will kiss it better. Is this also a magical touch of faith? I think it is a vivid and early illustration of what many people in later life find out: that the interest and attention and the genuinely professional affection of the caring professions is what makes them effective. Paul Halmos, ${ }^{8}$ a professor of sociology who wrote The Faith of the Counsellors deals at length with the importance of love in such caring relationships as social workers seek to use in their work.

In my view it is not simply love (as Halmos describes it) that matters in a caring relationship, but rather what we might call (with apologies to St Paul) faith working through love. This has, within their discipline, been shown amply by psychoanalytical writers. I am not, of course, saying that the psychotherapist is kissing it better and healing the hurt in that way. Indeed the first thing laid down is that there shall be no physical contact between therapist and client - no healing touch, and certainly no kiss (maternal or otherwise). But the vast literature on what psychoanalysts after Freud have called the transference deals with how the client in his sessions develops and feels a close relationship with his analyst. In one view the client is bound to re-live and in some sense to recapitulate his earlier feelings for his mother and others. Whatever view we take of this, we cannot doubt that the affectional bond between the healed and the healer is illuminated by psychoanalytical work. It is helpful to remember the possibility of a sexually eroticised transference relationship. And healers of all kinds might be less naive if they remembered that their feelings for their clients (described as countertransference) may also become eroticised.

Thus physical and psychological explanations may help to shed some light on how the hands of the healer may work. There is wide interest (often of an odd kind) in spiritual aspects of this process: it sometimes looks as if we are seeing a recrudescence of the mediaeval and later preoccupations with the demonic and magical aspects of healing. As a soundly based faith has retreated in the West, so magic and superstition seem to threaten to take over. Exorcism is an example of what I mean. I 
recently took part in a seminar where we were discussing the tragic results of an exorcism. The hands of the two 'healing' exorcists had resulted in the death of the woman who was being exorcised (they caused a ruptured liver and she bled to death). Such horrifying results are unusual, but they show the dangers of a faith which is uninformed and has led, as in earlier practices like those of the Inquisition, to hateful violence. But exorcism and related problems are outside the scope of this paper.

Healing is always a social process to some extent. The social setting is therefore relevant, and the cultural background of traditional healers is increasingly being studied. I have written from the standpoint of a doctor working in Great Britain who has noted in the last twenty-five years striking changes in expectations about healing. Pressures of time and space limit my final comments to my own culture.

Healing has become an overvalued idea and an overworked word. To take the example of the Christian churches, Scorer ${ }^{9}$ in a recent review refers to the breathtaking comprehensiveness of such words as these: 'the Churches are being called to mediate this kind of spiritual influence that will lead to healing of every sort, healing of individuals and communities, healing of society and nations.' The word healing becomes so wide in its application that its meaning becomes diluted and superficial and ultimately its true meaning is lost.

In the process of rediscovering healing many healers carefully avoid the issue of whether their work involves miraculous or divine healing: yet that is certainly what many who seek healing expect. Earlier generations of Christians were supported by a belief in divine providence and a doctrine of suffering which helped them to bear life's afflictions nobly. There was often a supportive community which shared their beliefs and demonstrated an ampler faith working through a more practical love in action. Faith healing can intrude on such a scene and the healer can appear like a comet leaving a trail of esoteric interest.

When the hands of the healer fail to heal, what then? The most cruel assertion is that failure is due to lack of faith in the patient or client: this in my experience can lead to disastrous depression and distress for the individual and his family. I consider that a reappraisal of the headlong rush into Healing is long overdue in those churches which have made it a focus of energy which might better be expended elsewhere. For faith can be tested, the results can be looked at carefully. Edmunds and Scorer ${ }^{10}$ in a valuable recent review show how such studies are readily available. Louis Rose ${ }^{11}$ analysed 96 cases of purported faith cures and failed to be convinced of the efficacy of faith healing. A surgeon in America ${ }^{12}$ worked with Miss Kathryn Kuhlman in her great healing services and wrote of how whatever good she was doing was not far outweighed by the pain she was causing, and the bitter disappointments.
There are classical examples of the healers who fail to be, themselves, healed. St Paul the apostie, who had used the gift of healing, described how his thorn in the flesh was not removed in spite prayer. I think it should also be remembered that St Paul sometimes had to leave a sick colleague witout being cured. It is also important to note that Luke the beloved physician was often with St Pamul and one cannot but assume that his ministrations were welcome. Those Christians who are happy to follow in the tradition which St Paul describes .90 well have had, I think, a clear attitude to faith healing. They have believed that all healing comes from God, and that they may use medical and other means in their sicknesses as well as relying on prayer and the ministry of the church. They haze not, usually, believed that faith healing is some magic and automatic process: their faith in Gord (using the word faith in its special Christian sense $9 t$ this point) leads them to look to Him sometimes for miraculous healing if $\mathrm{He}$ so wills it. This is hard saying for the modern follower of faith heales. I agree with a former Bishop of Durham ( $\mathrm{H}$ Hensley Henson $)^{13}$ whose words are quoted by Edmunds and Scorer:

Suffering saddens and perplexes, but it does not alienate us, for under the bitter covenant of pain all must live and He suffers with us; but the partiality of favouritism, which grants exemptio from the general curse, not on any intelligibde principle or in the service of any adequate case, b $\overline{Q t}$ by mere caprice at this shrine, or at that man?s hands, alarms and revolts us. Not the credit of churches, but the character of God is the issue at stake in this controversy. 'Shall not the Judge of the earth do right?'

Such trenchant words remind us that the hands of the healer beckon us to consider deeper, wide and larger issues. It requires a consideration not only of the nature of faith, but of what we belieg about the nature of man and of his relationship to God. No glib reference to a touch of faith shoufa be allowed to obscure these other considerations. $\frac{D}{9}$

\section{References}

${ }^{1}$ Green, L (1980). A touch of faith In: $B M A$ neros review, May.

${ }^{2} L$ ewis, I M (197I). Ecstatic religion, Penguin, London ${ }^{\omega}$

3Gardner, $\mathrm{H}$ (1978). The composition of four quartets, Faber, London.

'Dearing, T (1977). England's exorcist tells about supe fo natural superpowers, New Jersey, Logos International.

${ }^{5}$ The Gospel of Mark, chap 5, v. 26 (Revised Standara Version).

'Frank, Jerome (196I). Persuasion and healing, Ne寅 York, Schocken.

7Goldberg, D (1978). The nature of psychological healing. In Current themes in psychiatry $\mathbf{I}$, Gaind R N and Hudson, B L (ed), London, Macmillan. 
'Halmos, Paul (1978). The faith of the counsellors, Second edition. London, Constable.

'Scorer, C G (1979). Healing: biblical, medical and pastoral. London, Christian Medical Fellowship Publications.

${ }^{10}$ Edmunds, V and Scorer, G (1979). Some thoughts on faith healing, Third edition. London, Christian Medical Fellowship Publications.
11Rose, L (1968). Faith healing. London, Victor Gollanz.

12Nolen, W A (1974). Healing: $a$ doctor in search of a miracle. Connecticut, Fawcett Publications Greenwich.

${ }^{18}$ Henson, H Henley (1925). Notes on spiritual healing Williams $\mathcal{E}$ Norgate.

\section{Journal of medical ethics}

Our last issue, September I980 contained the following papers:

\section{Contents}

\section{Editorial}

Surgery for the mind

Good television - indifferent ethics

\section{Focus}

The hospital as a place of pain

$D W$ Vere

\section{Main articles}

Doctors and torture: the police surgeon

Stanley $H$ Burges

Doctors and torture: an experience as a prisoner

Alfredo fadresic

Homosexuality and freedom of speech $R D$ Catterall

Psychosocial aspects of homosexuality Sidney Crown

Biological aspects of homosexuality Malcolm MacCulloch

Attitudes to medical ethics among British Muslim medical practitioners Aminah Molloy
Teaching medical ethics:

Ljubljana school of medicine, Yugoslavia Fanez Milčinski and

II5 Štefan Stražiščar

II6

Ethical considerations of psychosurgery: the unhappy legacy of the pre-frontal lobotomy

II7 Larry $O$ Gostin

Commentary PK Bridges

Case conference

As the buds so the flowers:

a discussion of medical education

\section{Letter from Australia}

Coming of age

128 Anthony $R$ Moore

I30 Medical groups

Book reviews

News and notes

139 Lectures and symposia 